\title{
Both Ethanol and Ethyl Acetate Curcuma Zedoaraia Extract was Capable of Inducing Cells Death in T47D Cell Line Culture
}

\author{
Titiek Sumarawati ${ }^{1, *}$, Chodidjah ${ }^{2}$, Taufiqurrachman Nasihun ${ }^{3}$
}

Titiek Sumarawati ${ }^{1, *}$, Chodidjah ${ }^{2}$, Taufiqurrachman Nasihun ${ }^{3}$

'Department of Chemistry, Medical Faculty, Sultan Agung Islamic University, Central Java - 50112, INDONESIA.

${ }^{2}$ Department of Anatomy, Medical Faculty,

Sultan Agung Islamic University, Central Java - 50112, INDONESIA.

${ }^{3}$ Department of Biochemistry, Sultan Agung Islamic University, Semarang, Central Java 50112, INDONESIA.

\section{Correspondence}

\section{Titiek Sumarawati}

Department of Chemistry, Medical Faculty, Sultan Agung Islamic University, Central Java - 50112, INDONESIA.

E-mail: sumarawati@unissula.ac.id

History

- Submission Date: 05-01-2021;

- Review completed: 11-02-2021;

- Accepted Date: 08-03-2021.

DOI : 10.5530/pj.2021.13.94

Article Available online

http://www.phcogj.com/v13/i3

\section{Copyright}

(C) 2021 Phcogj.Com. This is an openaccess article distributed under the terms of the Creative Commons Attribution 4.0 International license.

\begin{abstract}
Introduction: Curcuma zedoaria (CZ) has been proven capable of inducing apoptosis in cells cancer. CZ extraction can be performed by ethanol and acetyl acetate as solvent. However, which one of these extracts is superior remains unclear. Objective: This study aimed to investigate the difference potential effect of ethanol and acetyl CZ extract on apoptosis of T47D cell line. Methods: In this study 21 wells were assign into seven groups: control group (T47D); treatment groups consisting of group of ethanol CZ extract 46 (EtZ-46); group of ethanol CZ extract 23 (EtZ-23); group of ethanol CZ extract 11 (EtZ-11); and group of ethyl acetate CZ extract 111 (AcZ-111); group of ethyl acetate CZ extract 55 (AcZ-55); and group of ethyl acetate CZ extract 27 (AcZ-27). In T47D group only loaded with T47D cell line; in treatment groups aside from loaded with T47D cell line culture, also treated with ethanol or acetyl acetate CZ extract respectively. Concentration of T47D cell was $5 \times 10^{4}$ T47D cells line in $100 \mu$ suspension loaded on each well of 21 wells and kept in $\mathrm{CO}_{2}$ incubator overnight. The apoptosis cells were measured after 48 hours post CZ treatment. Results: Post Hoc analysis indicated that the number of apoptosis cells in AcZ-111 was significant higher compared to that of other groups, $p<0.05$. Conclusion: Acetyl acetate $C Z$ extract treatment with dose $111 \mu \mathrm{g}$ was capable of inducing apoptosis in T47D cell line superior than that of other groups including ethanol CZ extract.
\end{abstract}

Key words: Curcuma zedoaria, Apoptosis, Necrosis, T47D cell line, Ethanol, Acetyl acetate.

\section{INTRODUCTION}

Data from World Health Organization (WHO) indicated that breast cancer $(\mathrm{BC})$ is the most prevalent cancer in female. Incidence of $\mathrm{BC}$ in the world is 2.1 million per year, constituting the greatest number of cancer related death. In 2018, the number of breast cancer related death was 627.000 or around $15 \%$ of all cancer death. ${ }^{1,2}$ Albeit, the incidence of $\mathrm{BC}$ was higher in developed countries, however, its percentage is increasing in almost each region globally. ${ }^{1}$ In US, for instance, new invasive case of BC was estimated to be 268.600 in 2019, and approximately $41.760(15.5 \%)$ of them are expected to die. ${ }^{3}$ Likewise, in Asia, there were increasing new cases of BC among women in Pakistan, China, India, and Thailand during 19902015. ${ }^{4}$ Fortunately, from 1989 to 2017 , the mortality rate of BC has reduced significantly about $40 \%$, resulting in $375.900 \mathrm{BC}$ death can be averted. ${ }^{3}$ The decrease in $\mathrm{BC}$ mortality rate was attributable to screening program, improvement of treatment, earlier detection, and adjuvant therapy originate from botanical product. ${ }^{3,5,6}$ Curcuma zedoaria (CZ) is a botanical product has been proven capable of inducing apoptosis on various cells such as Daltons Lymphoma Ascites (DLAs), Lung Carcinoma (A549), nasopharyngeal carcinoma (KB), leukemic (K562), and T47D cell lines. ${ }^{6,7} \mathrm{My}$ own study that have been published indicated that the potential effect of water extract of $\mathrm{CZ}$ on T47D cells apoptosis remains low, less than $10 \% .{ }^{6}$ On the other hand, some evidences showed that both ethanol and ethyl acetate CZ extract has been proven capable of inducing apoptosis on various cancer cells. ${ }^{6-8}$ However, the potential effect of ethanol and ethyl acetate CZ extract which one is more effective on T47D cells apoptosis remain unclear.

Curcuma zedoaria is also known as white turmeric, family of Zingiberacea contain various chemical elements such as sesquiterpene, phenylpropanoids, flavonoids, and terpenoids. ${ }^{6}$ Based on these constituents, $\mathrm{CZ}$ possess several medical benefits such as antioxidant, anti-inflammation, antimicrobial, anti-angiogenesis, and antitumor activities. ${ }^{9}$ Amongst these chemical components, polyphenol and flavonoids are the most prominence substance which is utilized widely as cancer chemoprevention and adjuvant therapy. ${ }^{10}$ In Indonesia CZ have been traditionally used as such BC therapy and recently proven capable of inhibiting cancer cell progression. ${ }^{11}$ In addition, some studies also indicated that flavonoids have been proven capable of killing cancer cell. ${ }^{10,12}$ Another study was reported by Lakshmi S, et al demonstrated that purified extract of $\mathrm{ZC}$ containing Isocurcumenol was able to increase apoptosis capacity in various cells, as well as inhibit cell proliferation. ${ }^{7}$ Moreover, treatment with ethanol $\mathrm{CZ}$ extract at the dose of $300 \mathrm{mg} / \mathrm{kg}$ and $750 \mathrm{mg} / \mathrm{kg}$ body weight (BW) was also able to inhibit expression of p53 and H-Ras in mutant mammary gland cells. ${ }^{6}$ In addition to ethanol extraction, flavonoids of plants also can be extracted and fractionated by ethyl acetate solvent, resulting in high phenolic and flavonoids constituent with antioxidant highest activity. ${ }^{13,14}$ 
Based on these data, both ethanol and ethyl acetate extraction of CZ, can be expected more efficacious in inducing $\mathrm{BC}$ cells apoptosis than that of water extraction.

Apoptosis is the intrinsic cell suicide program, aimed to eliminate virus and unwanted cell in normal cells and tissues development. ${ }^{15},{ }^{16}$ Accordingly, when apoptosis does not work appropriately abnormal cells proliferation and cancer may be developed. Apoptosis can be induced by stress oxidative, characterized by imbalance between oxidant and antioxidant concentration. There are growing evidences that increase in concentration of reactive oxygen species (ROS) is able to trigger lipid peroxidation, deoxyribose nucleic acid (DNA) damage, and apoptosis marked by nuclear fragmentation, chromatin condensation, and membrane blebbing. ${ }^{17,18}$ In this study, T47D cell line was used as such representative of BC luminal subtype due to the appropriateness of estrogen and progesterone specific effect. It was supported by a study reported by $\mathrm{Yu} \mathrm{S}$, et al. indicated that T47D cell line is an ideal experimental model as such representation of luminal subtype of BC sensitive to estrogen-progesterone effect. ${ }^{19}$ Some evidences also suggested that T47D cell lines contain p53 alteration, hence incapable to control cell cycle, protect DNA from damage, inhibit apoptosis, subsequently give rise breast cancer formation. ${ }^{17,18,20}$

Objective of the study was to elucidate the difference effect of ethanol and ethyl acetate CZ extract treatment on apoptosis capacity in T47D cell lines.

\section{METHODS}

In this posttest only control group design, 21 wells were assigned into seven groups, consisting of three wells of each. Group 1: control group (T47D); group 2: group of ethanol CZ extract 46 (EtZ-46); group 3: group of ethanol CZ extract 23 (EtZ-23); group 4: group of ethanol CZ extract 11 (EtZ-11); group 5: group of ethyl acetate CZ extract 111 (AcZ-111); group 6: group of ethyl acetate CZ extract 55 (AcZ-55); and group 7: group of ethyl acetate CZ extract 27 (AcZ-27). In T47D group as such control group was only loaded with suspension of T47D cell line. In contrary, in the treatment groups, aside from loaded with T47D cell line also treated with ethanol CZ extract (EtZ-46, EtZ-23, EtZ-11) and ethyl acetate CZ extract (EcZ-111, EcZ-55, EcZ-27). Concentration of T47D cell line was loaded in each well of 21 wells is 5 $\mathrm{x} 10^{4} / 100 \mu \mathrm{l}$ suspension respectively and kept in $\mathrm{CO}_{2}$ incubator at $37^{\circ} \mathrm{C}$ temperature for 24 hours. The number of cell apoptosis was analyzed by flow cytometry at 48 hours post CZ treatment. This study was approved by Ethics Committee of the Faculty of Medicine, Sultan Agung Islamic University Semarang.

\section{Extract of curcuma zedoaria}

Curcuma zedoaria acquired from marketplace was cleaned, cut up, dried up, and pulverized. The arid CZ powder then weighed, and $400 \mathrm{~g}$ of it was divided into two parts 200 gram of each respectively. The first 200 gram of dry CZ then was extracted by Soxhlet method with ethanol as such solvent, meanwhile the second was extracted by the same method but utilize ethyl acetate as solvent. The extracts were concentrated and evaporated by a rotary evaporator. The extraction process was conducted in the Chemical laboratory of Sultan Agung Islamic University Medical Faculty, Semarang, Central Java Indonesia.

\section{Dosing for cell treatment}

The dose of CZ extract was created by firstly weighing $200 \mu \mathrm{g} \mathrm{CZ}$ and then added $1 \mathrm{ml}$ DMSO $1 \%$ result in $2 \mathrm{mg} / \mathrm{ml} \mathrm{CZ}$ as such stock liquid. To determine $46 \mu \mathrm{g} / \mathrm{ml}$ dose ( $\mathrm{IC}_{50}$ ), $184 \mu \mathrm{l} \mathrm{CZ}$ extract was taken from available stock liquefied and $7.816 \mu \mathrm{l}$ culture medium then added. From $46 \mu \mathrm{g} / \mathrm{ml}$, the dose of $23 \mu \mathrm{g} / \mathrm{ml}\left(\mathrm{IC}_{25}\right)$ can be determined, likewise, from $23 \mu \mathrm{g} / \mathrm{ml}$, the dose of $11 \mu \mathrm{g} / \mathrm{ml}\left(\mathrm{IC}_{125}\right.$ ) can be determined. By the similar method the dose of acetyl acetate CZ extract can be created.

\section{T47D cell culture}

T47 D cells were cultured in Roswell Park Memorial Institute (RPMI) 1640 medium, then supplemented with $10 \%$ fetal bovine serum (FBS) and $40 \mathrm{mg} / \mathrm{L}$ gentamicin. Cells were maintained at $37^{\circ} \mathrm{C}$ in a humidified atmosphere of $5 \% \mathrm{CO} 2$ and $95 \%$ air.

\section{Measurement of apoptotic cells}

Following T47D had been treated with ethanol and ethyl acetate CZ extract, apoptosis of T47D cells was measured by flow cytometry used FITC apoptosis detection kit with Propidium Iodide (Sigma-Aldrich). In this flow cytometry, Annexin V was utilized to identify apoptosis cells by its capability to bind phosphatidylserine discovered in the outer part of the plasma membrane. In normal cell phosphatidylserine is concealed within plasma membrane, nevertheless in apoptosis phosphatidylserine initially located in cytoplasmic is translocated to the cell surface, constituting an endpoint marker of early and late cells apoptosis.

\section{Statistical analysis}

The total number of cell apoptosis were presented as the mean \pm SD, and the differences between groups were analyzed using Anova followed by Post Hoc LSD test. The result of statistical analysis is considered significant when $\mathrm{p}$ value $<0.05$.

\section{RESULTS}

Following treatment with ethanol and ethyl acetate $\mathrm{CZ}$ extract at specific dose on T47D and incubated for 48 hours, the result can be summarized in Table 1.

This result indicated that the highest number of viable cells was in T47D, followed by AcZ-27, EtZ-46, EtZ-23, EtZ-11, AcZ-55, and the lowest was in AcZ-111. On the other hand, the highest number of apoptosis cells was in AcZ-111, followed by AcZ-55, EtZ-46, EtZ-23, EtZ-23, T47D, and the lowest was in AcZ-27. Moreover, the highest number of necrotic cells was in EtZ-11, followed by EtZ-23, AcZ-55, EtZ-46, AcZ-111, AcZ-27, and the lowest was in T47D (Figure 1). In order to determine whether the statistical difference significantly amongst group occur, one-way ANOVA statistical analysis was performed. The results showed that the number of viable, apoptosis, and necrotic cells amongst groups were significantly different, $p<0.05$. Furthermore, to determine the difference between two groups, Post Hoc analysis was done, and the results as described below.

\section{Number of viable cells}

Post Hoc analysis demonstrated that number of viable cells in EtZ-46, EtZ-23, EtZ-11, EcZ-111, and EcZ-55 was significant lower compared to that of T47D, $p<0.05$. On the other hand, the number of viable cells in EcZ-27 was not significant difference compared to that of T47D, $p>0.05$. Moreover, the number of viable cells in AcZ-111 was significant lower compared to that of AcZ-27, AcZ-55, EtZ-11, EtZ-23, and EtZ-46, $\mathrm{p}<0.05$. The number of viable cells in EcZ-111 was significant lower compared to that of EcZ and EtZ groups, $\mathrm{p}<0.05$ respectively (figure $2 \mathrm{~A}$ ). These results suggested that following treatment of both EcZ and EtZ CZ extracts T47D cells were incapable of maintaining cells in surviving.

\section{Number of apoptosis cells}

According to Post Hoc analysis indicated that number of apoptosis cells in EtZ-46, EtZ-23, EtZ-11, EcZ-111, and EcZ-55 was higher significant compared to that of $\mathrm{T} 47 \mathrm{D}, \mathrm{p}<0.05$. In contrary, the number of apoptosis cells in AcZ-27 was no significant lower compared to that of T47D, $p>0.05$. Moreover, the number of apoptosis cells in AcZ-111 and AcZ-55 was significant higher compared to that of EtZ-46, EtZ- 
Table 1: Mean of apoptosis cells following treatment with ethanol and ethyl acetate CZ extract.

\begin{tabular}{|c|c|c|c|c|c|c|c|c|}
\hline Variables & $\begin{array}{c}\mathrm{T} 47 \mathrm{D} \\
\mathrm{N}=3 \\
\mathrm{X}( \pm \mathrm{SD})\end{array}$ & $\begin{array}{c}\text { EtZ-46 } \\
N=3 \\
X( \pm S D)\end{array}$ & $\begin{array}{c}\mathrm{EtZ}-23 \\
\mathrm{~N}=3 \\
\mathrm{X}( \pm \mathrm{SD})\end{array}$ & $\begin{array}{c}\text { EtZ-11 } \\
\mathrm{N}=3 \\
\mathrm{X}( \pm \mathrm{SD})\end{array}$ & $\begin{array}{c}\text { AcZ-111 } \\
N=3 \\
X( \pm S D)\end{array}$ & $\begin{array}{c}\text { AcZ-55 } \\
N=3 \\
X( \pm S D)\end{array}$ & $\begin{array}{c}\text { AcZ-27 } \\
N=3 \\
X( \pm S D)\end{array}$ & $\begin{array}{c}P \\
\text { (Anova) }\end{array}$ \\
\hline Viable Cells (\%) & $96.21( \pm 0.30)$ & $\begin{array}{c}48.71 \\
( \pm 0.54)\end{array}$ & $\begin{array}{c}61.45 \\
( \pm 0.58)\end{array}$ & $\begin{array}{c}81.96 \\
( \pm 0.03)\end{array}$ & $\begin{array}{c}6.02 \\
( \pm 0.65)\end{array}$ & $\begin{array}{c}25.48 \\
( \pm 1.25)\end{array}$ & $\begin{array}{c}95.36 \\
( \pm 0.11)\end{array}$ & 0.000 \\
\hline Apoptosis Cells (\%) & $3.22( \pm 0.40)$ & $\begin{array}{c}15.52 \\
(+0.47)\end{array}$ & $\begin{array}{c}15.13 \\
( \pm 0.57)\end{array}$ & $\begin{array}{c}13.28 \\
( \pm 0.01)\end{array}$ & $\begin{array}{c}92.24 \\
( \pm 0.63)\end{array}$ & $\begin{array}{c}62.04 \\
( \pm 0.25)\end{array}$ & $\begin{array}{c}3.10 \\
(+0.23)\end{array}$ & 0.000 \\
\hline Necrotic Cells (\%) & $0.56(+0.37)$ & $\begin{array}{c}35.77 \\
(+0.01)\end{array}$ & $\begin{array}{c}23.42 \\
( \pm 0.02)\end{array}$ & $\begin{array}{c}4.75 \\
(+0.03)\end{array}$ & $1.72( \pm 0.02)$ & $\begin{array}{c}12.46 \\
( \pm 1.01)\end{array}$ & $\begin{array}{c}1.53 \\
(+0.12)\end{array}$ & 0.000 \\
\hline
\end{tabular}
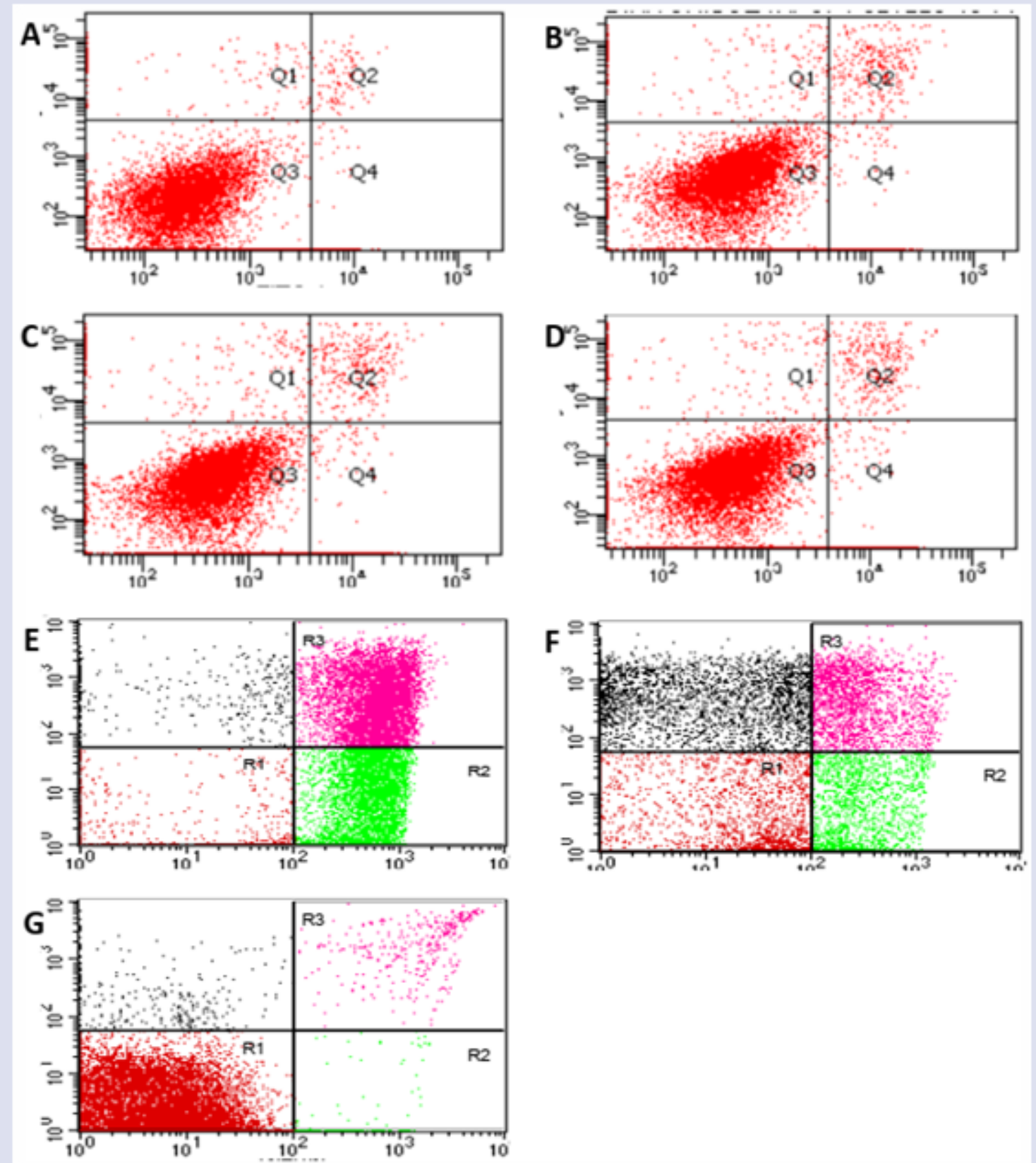

Figure 1:T47D cells viable, apoptosis, and necrosis were obtained from Flow cytometry assessment methods following ethanol and ethyl acetate CZ extract treatments: A. T47D (control); B. EtZ-46; C. EtZ-23; D. EtZ-11; E. EcZ-111; F. EcZ-55; and G. EcZ-27 groups. 
23, and EtZ-11, $<<0.05$. Meanwhile, the number of apoptosis in EtZ23 was not significant lower compared to that of EtZ-46, $p>0.05$. The number of apoptosis cells in AcZ-111 was significant higher compared to that of AcZ-55, $p<0.05$. Taken together, T47D apoptosis cells in ethyl acetate $\mathrm{CZ}$ extract was significant higher compared to that of ethanol $\mathrm{CZ}$ extract (figure 2B).

\section{Number of necrotic cells}

Post Hoc statistical analysis indicated that number of necrotic cells in EtZ-46, EtZ-23, EtZ-11, EcZ-111, and EcZ-55, was significant higher compared to that of $T 47 \mathrm{D}, \mathrm{p}<0.05$. On the other hand, albeit the number of necrotic cells in EcZ-27, was higher compared to that of T47D, however, the difference was not significant, $p>0.05$. In addition, the number of necrotic cells in EtZ-23 and EtZ-11 were higher significantly compared to that of AcZ-11, AcZ-55, and AcZ-111, $\mathrm{p}<0.05$ respectively (figure 1C). These results suggested that the number of T47D cells necrotic in ethanol CZ extracts were higher compared to that of ethyl acetate $\mathrm{CZ}$ extract (figure $2 \mathrm{C}$ ).

\section{DISCUSSION}

The result of the present study revealed that both ethanol and acetyl acetate CZ extract treatment was capable of inducing apoptosis and necrotic cells in T47D cell line culture. This result is in line with a study was reported by Lourembam et al. show that ethyl acetate CZ extract could induce apoptosis in MDA-MB23 cells mediated by caspase pathway. ${ }^{21}$ The lowest result amongst doses of $\mathrm{CZ}$ ethanol extract on the number of apoptosis cells was at the dose of $11.5 \mathrm{mg}$ extracts, meanwhile at the dose of 46 and $23 \mathrm{mg}$ yield a comparable result. On the other hand, the best result of ethyl acetate $\mathrm{CZ}$ extracts on the number of apoptosis cells was at the dose of 111.5 and $55 \mathrm{mg}$ of ethyl acetate CZ extract. Meanwhile, the apoptosis of T47D cells at the dose of $27.5 \mathrm{mg}$ was comparable to control group. In addition, the highest number of T47D cells necrosis in ethanol CZ extract was at the dose of 11.5 and 23 $\mathrm{mg}$, whereas the highest number of T47D cell necrotic of ethyl acetate $\mathrm{CZ}$ extract was at the dose of $55 \mathrm{mg}$. Moreover, the number of T47D necrotic cells at the dose of 111.5 and $27.5 \mathrm{mg}$ were comparable.

Albeit the result of the present study suggested that both ethanol and ethyl acetate CZ extracts were capable of inducing apoptosis and necrosis of T47D cell line culture, however, taken together the number of apoptosis cells in ethyl acetate CZ extract treatment was higher compared to that of ethanol $\mathrm{CZ}$ extract. In contrary, the number of necrotic cells in ethanol $\mathrm{CZ}$ extract was superior than that of ethyl acetate $\mathrm{CZ}$ extracts. Accordingly, these results implied that the effect of ethyl acetate $\mathrm{CZ}$ extract on apoptosis was superior than that of ethanol $\mathrm{CZ}$ extract, and otherwise occurring in cells necrosis. Interestingly, apoptosis T47D cells line both in ethanol and ethyl acetate CZ extracts were in the dose dependent manner (figure 3A)

Concern to the number of cells death due to combination of apoptosis and necrotic cells, the highest cell deaths was at dose of $111 \mathrm{mg}$ of

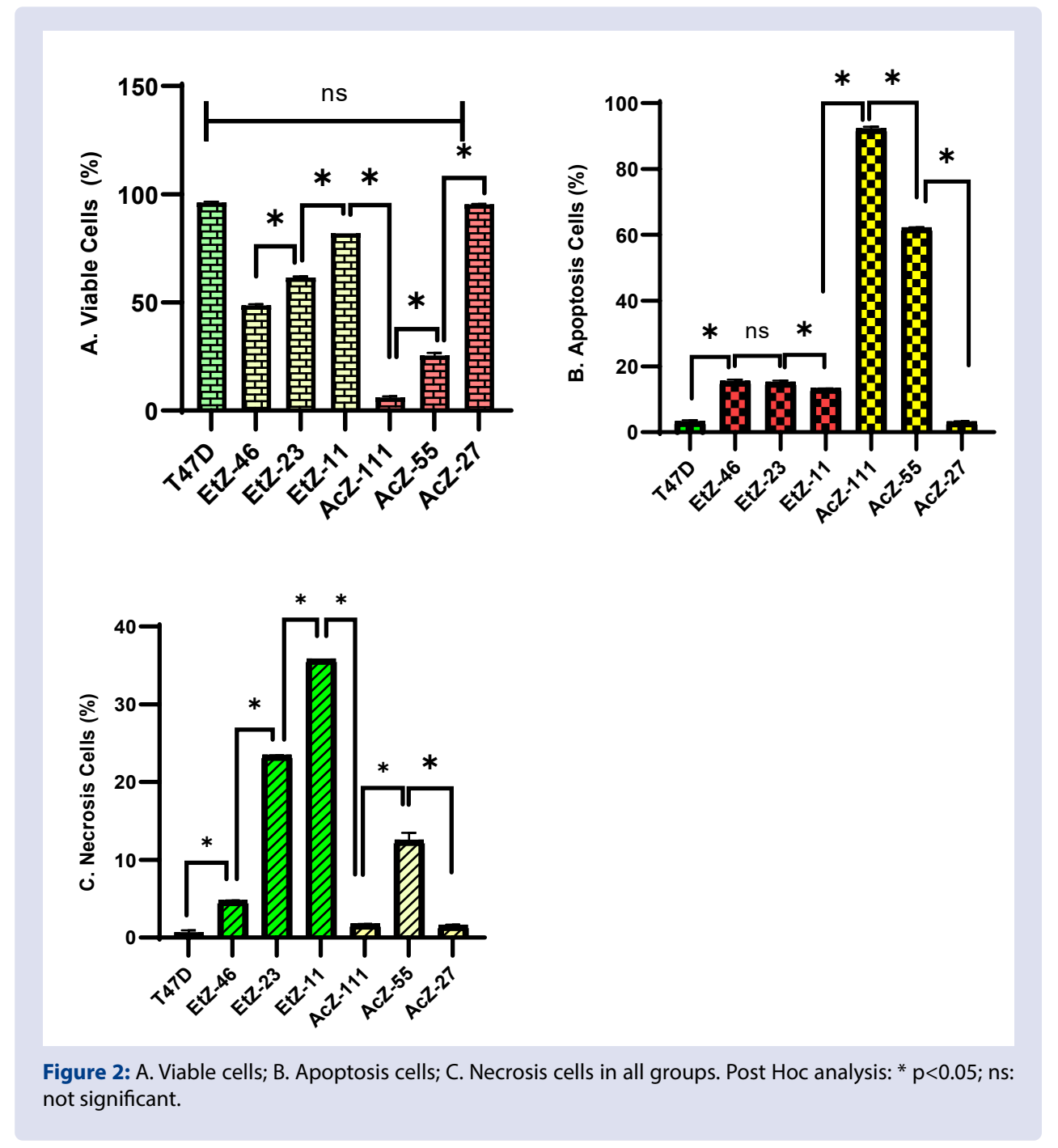




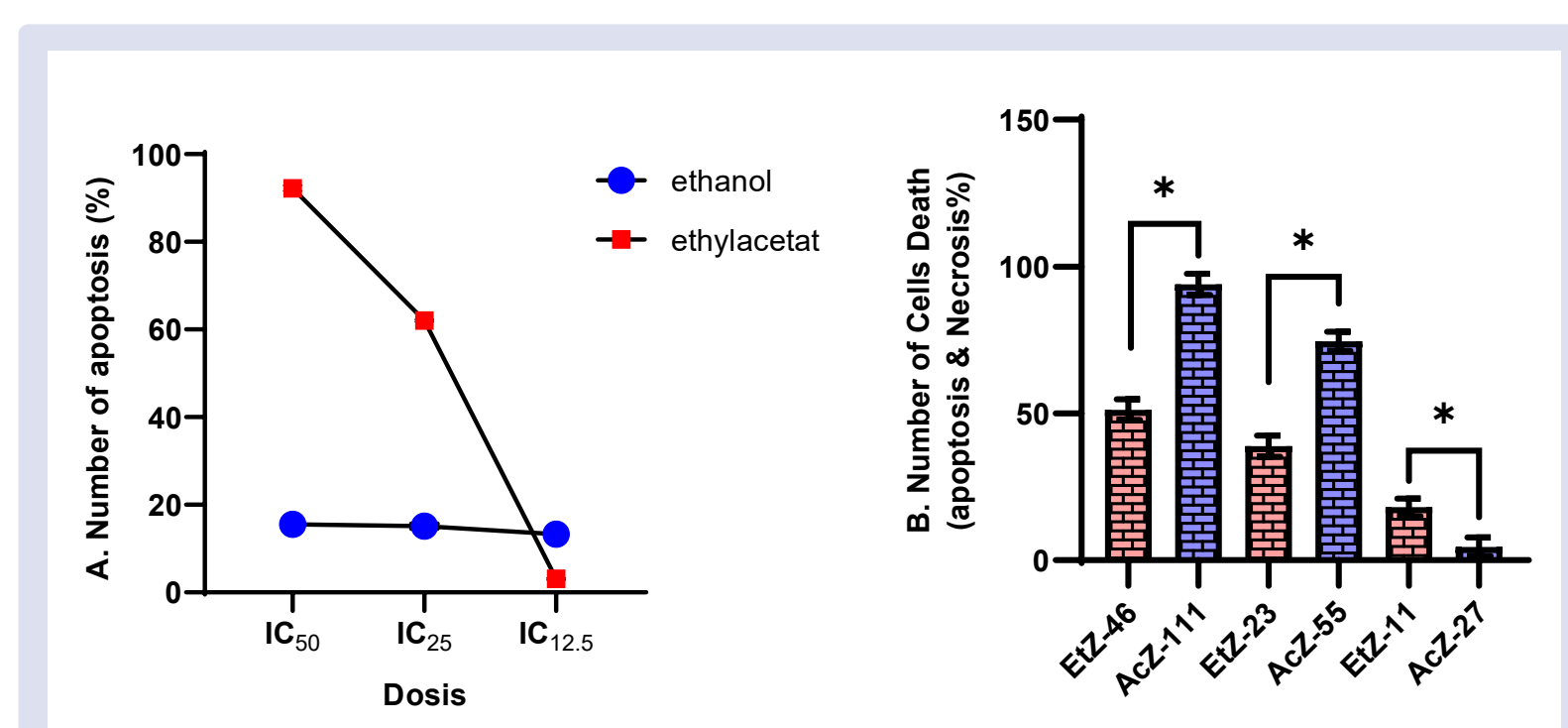

Figure 3: A. Number of cell death (apoptosis and necrosis) in each dose; B. Comparison of cell death between ethanol CZ extract and ethyl acetate $C Z$ extract. Post Hoc analysis: ${ }^{*} p<0.05$.

ethyl acetate CZ extract treatment. The $111 \mathrm{mg}$ was the highest dose of ethyl acetate CZ extracts. When the number of cells death at the dose of $111 \mathrm{mg}$ ethyl acetate $\mathrm{CZ}$ extracts compared to that of the highest dose of ethanol CZ extracts $46 \mathrm{mg}$, the number of cells death at $111 \mathrm{mg}$ ethyl acetate $C Z$ extract was significantly higher, $p<0.05$. (figure $3 B$ ). Otherwise, the number of cells death in ethyl acetate $\mathrm{CZ}$ extracts at the dose of $27 \mathrm{mg}$, the lowest dose of ethyl acetate CZ extracts was lower significant compared to that of $11 \mathrm{mg}$ dose, the lowest dose of ethanol $\mathrm{CZ}$ extracts. Moreover, the number of cells death in ethyl acetate $\mathrm{CZ}$ extracts at the dose of $55 \mathrm{mg}$, the moderate dose of ethyl acetate CZ extracts, was significant higher compared to that of $23 \mathrm{mg}$, the moderate dose of ethanol $\mathrm{CZ}$ extracts, $\mathrm{p}<0.05$. Taken together, the result of the present study demonstrated that treatment with ethyl acetate $\mathrm{CZ}$ extracts on T47D cells death due to both apoptosis and necrosis cells was superior than that of ethanol CZ extract.

The superiority of ethyl acetate CZ extract treatment on apoptosis of T47D cell lines is likely attributable to isocurcumenol which is contained in ethyl acetate CZ extract. A study was reported by Lakshmi, et al. demonstrated that treatment with sesquiterpenoid compound Isocurcumenol was extracted from $\mathrm{CZ}$, capable of inducing apoptosis in Daltons Lymphoma Ascites (DLAs), Lung Carcinoma (A549), nasopharyngeal carcinoma (KB), and leukemic (K562). ${ }^{7}$ The similar results were also reported by various studies, indicated that curcuminoids isolated from CZ had been proven capable of inducing apoptosis and inhibition of growth of ovarian cells carcinoma (Ovcar-3), leukemia (HL-60), and cells of mouse cervical carcinoma. ${ }^{7,22,23}$ In addition, essential oil contained in Curcuma wenyujin a close family of CZ extract also able to inhibit proliferation and induce apoptosis of cervical cancer cells and human hepatoma. ${ }^{23}$ Polysaccharide fraction, another substance contained in extract of Curcuma zedoaria was capable of reducing tumor size sarcoma 180 mouse likely associated with apoptosis. ${ }^{24}$

On the other hand, in the present study, treatment with ethanol CZ extract on T47D cell line showed that number of apoptosis was lower compared to that of ethyl acetate CZ extract. It was possibly related to polyphenol and flavonoids contained in ethanol CZ extract which serve as antioxidant. ${ }^{13,14,25}$ Some evidences indicated that $\mathrm{CZ}$ was extracted with ethanol as solvent yield three important substances such as curcumin, demethoxycurcumin, and bisdemothoxycurcumin, that capable of inhibiting and reversing of tumor growth. ${ }^{8,26,27}$ Several epidemiological studies have reported that botanical compound, which possess both antioxidant and anti-inflammatory properties capable of inhibiting carcinogenesis. ${ }^{8,28}$ Another study was reported by Do QD et al. had confirmed that Curcuma zedoaria was extracted by ethanol $100 \%$ capable of increasing antioxidant activity characterized by increasing DPPH radical scavenging activity, even its activity was in the highest level compared to that of other solvents including water, methanol, and acetone. ${ }^{25}$ These data imply that ethanol CZ extract possess both antioxidant and anti-tumor effect, however the anti-tumor effect of ethanol CZ extract was limited, whereas antioxidant property was prominent. Apoptosis of T47D cells is triggered by reactive oxygen species (ROS) formation, followed by DNA damage, decrease in mitochondrial membrane permeability and Bcl2 expression, and eventually caspase 3 activity. ${ }^{29}$ Accordingly, the ethanol CZ extract that contain high antioxidant polyphenol and flavonoids could not induce apoptosis optimally.

\section{CONCLUSION}

Treatment with both ethanol and ethyl acetate curcuma zedoaria extract were capable of inducing apoptosis of T47D cells line. However, the number of apoptosis was higher in ethyl acetate curcuma zedoaria than that of ethanol curcuma zedoaria extract.

\section{ACKNOWLEDGEMENTS}

Sultan Agung Islamic University support and funding this research.

\section{CONFLICTS OF INTEREST}

No conflict of interest to be declared related to data collection, statistical analysis, writing of the manuscript, and publish the results.

\section{REFERENCES}

1. World Health Organization (WHO). Breast cancer: Early diagnosis and screening. taken from https://www.who.int/cancer/prevention/ diagnosis-screening/breast-cancer/en/. September 2020.

2. Momenimovahed Salehiniya H. Epidemiological characteristics of and risk factors for breast cancer in the world. Breast Cancer (Dove Med Press). 2019;11:151-64.

3. American Cancer Society. Breast Cancer Facts \& Figures 2019-2020 Atlanta: American Cancer Society, Inc. 2019. 
4. Mubarik S, Malik SS, Wang Z, Li C, Fawad M, Yu C. Recent insights into breast cancer incidence trends among four Asian countries using age period-cohort model. Cancer Management and Research. 2019;11:8145-55.

5. Jemal A, Siegel R, Ward E, Hao Y, Xu J, Murray T, Thun MJ. Cancer statistics, 2008. CA: A Cancer Journal for Clinicians. 2008;58(2):7196.

6. Sumarawati T, Nasihun T, Chodidjah. Effect of Zamzam Water Extract of Curcuma zedoaria Treatment on Apoptosis, p53 and Bcl2 Protein Expression of T47D Cell Culture. Journal of Natural Remedies. 2018;18(3):101-6

7. Lakshmi S, Padmaja G, Remani P. Antitumour effects of isocurcumenol isolated from curcuma zedoaria rhizomes on human and murine cancer cells. International Journal of Medicinal Chemistry. 2011;253962:1-13.

8. Carvalho FR, Vassão RC, Nicoletti MA, Maria DA. Effect of Curcuma zedoaria crude extract against tumor progression and immunomodulation. J Venom Anim Toxins incl Trop Dis. 2010;16(2):324-41.

9. Peng $\mathrm{CH}$, Chiu WT, Juan $\mathrm{CW}$, Mau JL, Chen CC, Peng CC, et al. Pivotal role of curcuminoids on the antimutagenic activity of Curcuma zedoaria extracts. Drug and Chemical Toxicology. 2010;33:64-76.

10. Luo $X$.. The role of targeting kinase activity by natural products in cancer chemoprevention and chemotherapy (Review). Oncology Report. 2015;34:547-54.

11. Chodidjah, Widayati E, Taufiqurrachman Nasihun T. Treatment of Thyponium Flageliforme in Combination with Curcuma Zedoaria, and Phyllanthus Niruri Synergistically Enhances Apoptotic and AntiProliferative Effect on Breast Cancer. Journal of Natural Remedies. 2017;1-8.

12. Zhang HW, Hu JJ, Fu RO, Liu X, Zhang YH, Li J. Flavonoids inhibit cell proliferation and induce apoptosis and autophagy through downregulation of $\mathrm{PI} 3 \mathrm{~K} \gamma$ mediated PI3K/AKT/mTOR/p70S6K/ULK signaling pathway in human breast cancer cells. Scientific Reports. 2018;8:11255.

13. Abdel-Aleem ER, Attia EZ, Farag FF, Samy MN, Desoukey SY. Total phenolic and flavonoid contents and antioxidant, anti-inflammatory, analgesic, antipyretic and antidiabetic activities of Cordia myxa L. leaves. Clinical Phytoscience. 2019;5:29.

14. Prakosa DG, Andayani S, Maftuch M. In Vitro Phytochemical and Antibacterial Activity Test on Temu Putih Extract (Curcuma Zedoaria) Against Aeromonas Hydrophila. 2016; International Journal of Scientific \& Technology Research. 5(02):36-7.

15. Ho J. The regulation of apoptosis in kidney development: implications for nephron number and pattern? Frontiersin Pediatrics. 2014;2(128):16.

16. Taylor RC, Cullen SP, Martin SJ. Apoptosis: controlled demolition at the cellular level. Nat Rev Mol Cell Biol. 2008;9(3):231-41.
17. Lim LY, Vidnovic N, Ellisen LW, Leong CO. Mutant $\mathrm{p} 53$ mediates survival of breast cancer cells. British Journal of Cancer. 2009;101:1606-12.

18. Vallon $\mathrm{V}$. The proximal tubule in the pathophysiology of the diabetic kidney. AmJ Physiol Regul Integr Comp Physiol. 2011;300:R1009-22.

19. Yu S, Kim T, Yoo KH, Kang K. The T47D cell line is an ideal experimental model to elucidate the progesterone-specific effects of a luminal $A$ subtype of breast cancer. Biochemical and Biophysical Research Communication. 2017;486(3):752-8.

20. Nasihun T, Widayati E. Pimpinella Treatment on Reducing Apoptosis of Kidney Cells Following UVB Radiation in Rats. Pimpinella Treatment on Reducing Apoptosis of Kidney Cells Following UVB Radiation in Rats. Pharmacogn J. 2020;12(3):503-9.

21. Lourembam RM, Yadav AS, Kundu GC, Mazumder PB. Curcuma zedoaria (christm.) roscoe inhibits proliferation of MDA-MB231 cells via caspase-cascade apoptosis. Oriental Pharmacy and Experimental Medicine. 2019.

22. Lai EYC, Chyau CC, Mau Jl. Antimicrobial activity and cytotoxicity of the essential oil of Curcuma zedoaria, American Journal of Chinese Medicine, vol. 32, no. 2, pp. 281-290, 2004.

23. Lim CB, Ky N, Ng HM, Hamza MS, Zhao Y, "Curcuma wenyujin extract induces apoptosis and inhibits proliferation of human cervica cancer cells in vitro and in vivo," Integrative cancer therapies, vol. 9, no. 1, pp. 36-49, 2010

24. Kim KI, Kim JW, Hong BS, et al., "Antitumor, genotoxicity and anticlastogenic activities of polysaccharide from Curcuma zedoaria," Molecules and Cells, vol. 10, no. 4, pp. 392-398, 2000.

25. Do QD, Angkawijaya AE, Tran-Nguyen PL, Huynh LH, Soetaredjo FE, Ismadji $\mathrm{S}$, et al. Effect of extraction solvent on total phenol content, total flavonoid content, and antioxidant activity of Limnophila aromatica. journal of food and drug analysis. 2014;22:296-302.

26. Lobo R, Prabhu KS, Shirwaikar A, Shirwaikar A. Curcuma zedoaria Rosc. (white turmeric): a review of its chemical, pharmacological and ethnomedicinal properties. Journal of Pharmacy and Pharmacology. 2009;61:13-21.

27. Nishidono $Y$, Chiyomatsu T, Saifudin S, Deevanhxay P, Tanaka K. Comparative Study on the Chemical Constituents of Curcuma Drugs. Journal of the Asia-Japan Research Institute of Ritsumeikan University; 2:15-33.

28. Limtrakul P, Anuchapreeda S, Lipigorngoson S, Dunn FW. Inhibition of carcinogen induced c-Ha-ras and c-fos proto-oncogenes expression by dietary curcumin. BMC Cancer. 2001;1(1):1.

29. Chen X, Pei L, Zhong Z, Guo J, Zhang Q, Wang Y. Anti-tumor potential of ethanol extract of Curcuma phaeocaulis Valeton against breast cancer cells. Phytomedicine. 2011;18:1238-43. 


\section{GRAPHICAL ABSTRACT}

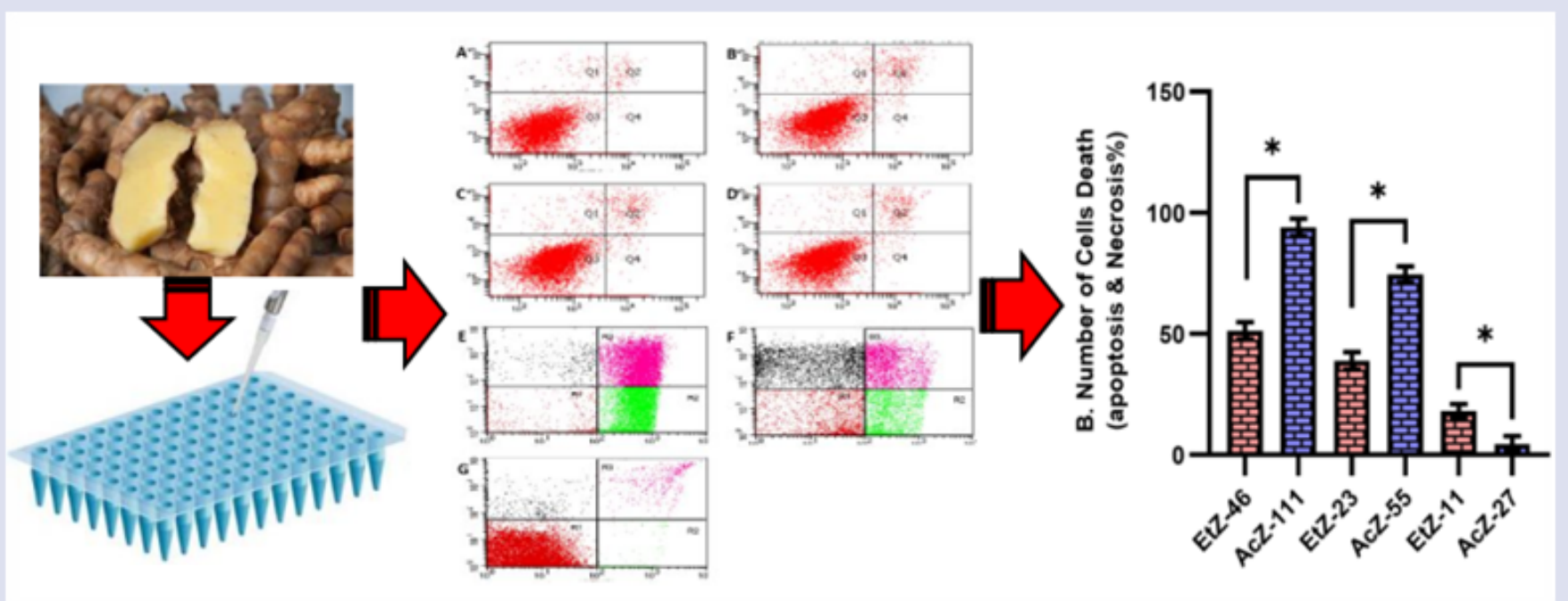

\section{ABOUT AUTHORS}

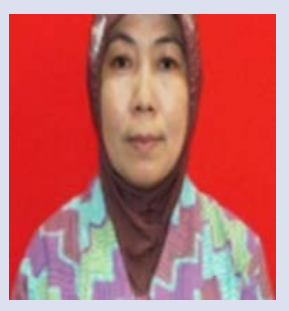

Titiek Sumarawati, Associate Professor in Medicinal Chemistry, received her doctoral degree at Diponegoro University Semarang in 2012. She is currently a lecturer at Universitas Islam Sultan Agung Semarang Indonesia. Her research interests are medicinal chemistry and drug discovery.

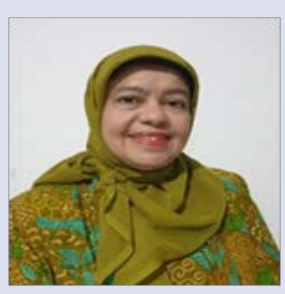

Chodidjah, Associate Professor in Anatomy, received her doctoral degree at Diponegoro university Semarang in 2013. Concern in medical Anatomy and Malignancy. She is also lecturer in medical Anatomy of medical faculty, Universitas Islam Sultan Agung and researcher in malignancy, particularly in breast cancer.

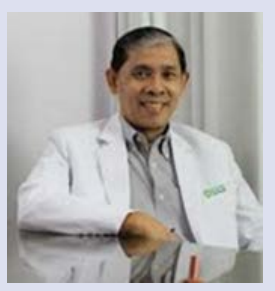

Taufiqurrachman Nasihun, Professor in medicine. Received his doctoral degree at Diponegoro university Semarang in 2007. He is specialist in andrology, consultant in sex and antiaging medicine, and concern in medical biochemistry. He is also lecturer in medical biochemistry of medical faculty, Universitas Islam Sultan Agung and researcher in botanical product.

Cite this article: Sumarawati T, Chodidjah, Nasihun T. Both Ethanol and Ethyl Acetate Curcuma Zedoaraia Extract was Capable of Inducing Cells Death in T47D Cell Line Culture. Pharmacog J. 2021;13(3): 737-43. 